\title{
Beta-Cyanoalanine Synthase as a Molecular Marker for Induced Resistance by Fungal Glycoprotein Elicitor and Commercial Plant Activators
}

\author{
Hideki Takahashi, Takeaki Ishihara, Shu Hase, Ayaka Chiba, Kazuhiro Nakaho, Tsutomu Arie, \\ Tohru Teraoka, Michiaki Iwata, Taneaki Tugane, Daisuke Shibata, and Shigehito Takenaka
}

First, second, third, and fourth authors: Department of Life Science, Graduate School of Agricultural Science, Tohoku University, Sendai 981-8555, Japan; fifth author: Department of Plant Pathology, National Agricultural Research Center, Tsukuba 305-8666, Japan; sixth, and seventh authors: Laboratory of Plant Pathology, Faculty of Agriculture, Tokyo University of Agriculture and Technology (TUAT), Tokyo 183-8509, Japan; eighth author: Agricultural \& Veterinary Research Labs., Meiji Seika Kaisha, Ltd., Yokohama 222-8567, Japan; ninth author: Chiba Prefectural Agriculture Research Center, Chiba 266-0006, Japan; tenth author: Kazusa DNA Research Institute, Kisarazu 292-0812, Japan; and eleventh author: Department of Upland Agriculture, National Agricultural Research Center for Hokkaido Region, Hokkaido 082-0071, Japan.

Accepted for publication 16 March 2006.

\begin{abstract}
Takahashi, H., Ishihara, T., Hase, S., Chiba, A., Nakaho, K., Arie, T., Teraoka, T., Iwata, M., Tugane, T., Shibata, D., and Takenaka, S. 2006. Beta-cyanoalanine synthase as a molecular marker for induced resistance by fungal glycoprotein elicitor and commercial plant activators. Phytopathology 96:908-916.

The biocontrol agent Pythium oligandrum produces glycoprotein elicitor in the cell wall fraction, designated CWP, and induces resistance to a broad range of pathogens. To understand the mechanism of CWPinduced resistance to pathogens, gene expression at the early stage of CWP treatment in tomato roots was analyzed using a cDNA array. At $4 \mathrm{~h}$ after CWP treatment, 144 genes were up-regulated and 99 genes were down-regulated. In the 144 up-regulated genes, nine genes exhibited about eightfold increased expression. Analysis of the response of these

gen cyanide $(\mathrm{HCN})$ detoxification enzyme, was stably induced in tomato roots by such treatment. However, expression of LeCAS was not significantly induced in tomato roots at $4 \mathrm{~h}$ by abiotic stresses, whereas only a very low level of induction of such expression by cold stress was observed. This LeCAS expression was also induced after exogenous treatment with a low level of 1-amino-cyclopropane-1-carboxylate as the precursor of ethylene, but not with either salicylic acid or methyl jasmonate. The induction of LeCAS expression in CWP-treated and plant activator-treated roots is likely to be caused by the detoxification of $\mathrm{HCN}$ during ethylene production. Transient activation of LeCAS expression caused by ethylene production in tomato roots may be a general phenomenon in fungal elicitor-induced and synthetic plant activator-induced resistance. LeCAS seems to be useful for screening possible novel plant activators for plant protection against pathogens.
\end{abstract} nine genes to three commercial plant activators indicated that a high level of one gene, beta-cyanoalanine synthase gene (LeCAS) encoding hydro-
Additional keywords: elicitin-like protein, global gene expression.
Once plants are infected by a pathogen, they are able to protect themselves against further infection (8). The existence of induced resistance, which is the acquired resistance to a broad range of pathogens in host plants previously infected with a pathogen or nonpathogenic microorganisms, is well documented (12,37). There are several types of induced resistance. One well-characterized type of induced resistance is systemic acquired resistance (SAR) in host plants infected with necrotizing pathogens $(12,29)$. At the molecular level, SAR is characterized by the expression of a large number of acidic pathogenesis-related (PR) genes and preceded by the accumulation of salicylic acid (SA). SA is thought to be a key signal molecule for SAR induction (14). Downstream of SA, NPRI/NIM1/SAII has been identified as an important component of SAR $(7,11,16,45)$. NPR1 interacts with the TGA family of basic leucine zipper transcription factors and positively regulates PR genes by either inducing a transcriptional activator or inhibiting a transcriptional repressor (12). 2,6-Dichloroisonicotinic acid (INA) is a synthetic compound that likely induces SAR via the

Corresponding author: H. Takahashi; E-mail address: takahash@bios.tohoku.ac.jp

DOI: 10.1094/PHYTO-96-0908

(C) 2006 The American Phytopathological Society same signal transduction pathway as SA $(11,32)$. However, SA and INA are not practically used in agriculture because some crops have insufficient tolerance to them.

Induced systemic resistance (ISR) in plants colonized with the nonpathogenic bacterium Pseudomonas fluorescens, which is another type of induced resistance response against a range of pathogens, has been well characterized at the molecular level (55, 57). Colonization of roots by $P$. fluorescens induces not only resistance to soilborne diseases but also resistance to pathogens in the whole plant. P. fluorescens WCS417r induces ISR via SAindependent signaling pathways and by jasmonic acid (JA) and ethylene-dependent signaling pathways, although ISR requires NPR1 as well as $\operatorname{SAR}(36,38,56)$.

Two major commercial compounds, i.e., benzo(1,2,3)thiadiazole-7-carbothioic acid S-methyl ester CGH-245 704 (BTH; Bion) and 3-allyloxy-1,2-benzisothiazole-1,1-dioxide (PBZ; Probenazole), have been developed as plant activators for disease control and have long been used practically in agricultural production (44,59). Studies using tobacco and Arabidopsis treated with these plant activators suggest that the mode of action of BTH and PBZ may be at least partially related to the SA-mediated signaling pathway because they activate the same set of PR genes in SA-treated plants $(13,17,26,27,63)$. However, the molecular mechanism(s) for induced resistance by $\mathrm{PBZ}$ and $\mathrm{BTH}$ remains to 
be determined. Recently, Ishikawa et al. (24) reported that validamycin A (VMA) acts to control tomato wilt disease caused by the soilborne fungus Fusarium oxysporum f. sp. lycopersici. Although VMA-treated plants accumulated SA and had an elevated expression of PR genes, our understanding of the signaling pathway(s) activated by VMA is insufficient.

Signal transduction pathways conferring induced resistance may be diverse among plant activators, fungal elicitors, and microorganisms as biocontrol agents. Induced resistance has been found to be differentially impaired in certain signaling mutants of Arabidopsis, indicating that different signaling pathways are activated by specific plant activators, fungal elicitors, or biocontrol microorganisms $(39,41)$. On the other hand, the coordination of defense-related gene expression and the accumulation of signal molecules (e.g., SA, JA, and ethylene) in plants treated with plant activators, fungal elicitors, and biocontrol microorganisms suggests that some parts of the signaling mechanism may be conserved $(15,37)$.

Besides chemical plant activators and $P$. fluorescens, some microorganisms that can induce resistance to a broad range of pathogens have been identified (6). Pythium oligandrum Drechs induces disease resistance to a number of soilborne plant pathogens by activation of plant defense mechanisms and by microbial antagonism caused by nutrient competition, parasitism, and production of antimicrobial substances $(2,3,28,30)$. Because the disease resistance induced by Pythium oligandrum is nonspecific in affording enhanced protection in different plant species against many pathogens, Pythium oligandrum has been focused upon as a potential biocontrol agent of soilborne plant pathogens. Several elicitin-like proteins have been identified in some Pythium spp. $(22,25,33,39)$. Oligandrin is a class I elicitin-like protein with a molecular mass of $\approx 10 \mathrm{kDa}$, which is secreted by Pythium oligandrum (35). A conclusive study on oligandrin-induced resistance against Phytophthora parasitica in tomato has suggested that oligandrin triggers cytological and biochemical modification in tomato cells, thereby inducing resistance to P. parasitica (35). Recently, Takenaka and Kawasaki (50) have also reported two types of cell wall protein fractions with elicitin activity from Pythium oligandrum (CWP). The amino acid sequences deduced from their corresponding cDNA sequences of POD-1 and POD-2 (DDBJ accession nos. AB217820 and AB217821) suggest that they have elicitin signatures (S. Takenaka, Y. Nakamura, T. Kono, H. Sekiguchi, A. Masunaka, and H. Takahashi, unpublished data). Pythium oligandrum CWP had elicitor activities that induced the defense reactions against pathogens in sugar beet and wheat. In the roots of sugar beet treated with CWP, the activities of phenylalanine ammonia lyase and chitinase and the amount of cell wallbound phenolic compounds increased (51). Induction of defenserelated gene expression by CWP treatment has also been observed in tomato plants (20). However, the mechanism for induced disease resistance in root tissues treated with CWP remains to be determined.

In this report, to study the molecular mechanism for CWPmediated induced resistance, global gene expression in CWPtreated roots of tomato was analyzed using an 11,520 nonredundant cDNA array. In the analysis of up-regulated genes in CWP-treated roots, we found that the expression of beta-cyanoalanine synthase gene (LeCAS) encoding hydrogen cyanide ( $\mathrm{HCN})$ detoxification enzyme was highly induced in tomato roots, not only by CWP treatment but also by PBZ, BTH, and VMA treatments, whereas it was not induced by several types of environmental abiotic stress. Identification of LeCAS, which is commonly up-regulated in tomato roots by fungal elicitors and commercial plant activators, indicates that the LeCAS-mediated HCN detoxification process may be associated with a conserved signaling pathway for induced resistance. In addition, LeCAS may be utilized as a universal marker for screening possible novel plant activators for plant protection against pathogens.

\section{MATERIALS AND METHODS}

Plant material. Lycopersicon esculentum cv. Micro-Tom, which is a laboratory-grown miniature tomato (46), was grown in quartz sand at $24^{\circ} \mathrm{C}$ in a growth chamber under continuous fluorescent light (7,000 lux) and fertilized with a thousand-fold diluted Hyponex solution at 3-day intervals (48).

Treatment with CWP of Pythium oligandrum. Fourteen-dayold tomato plants were carefully harvested from the plants grown in quartz sand with attention to minimizing the damage to the root tissue by injury. After the roots were rinsed with distilled water (DW) three times, the roots of one plant were dipped in $2 \mathrm{mg}$ of CWP per $\mathrm{ml}$ and incubated at $24^{\circ} \mathrm{C}$ under continuous fluorescent light (7,000 lux). CWP of Pythium oligandrum isolate MMR2 was prepared by a previously described method (51).

cDNA array preparation. The 11,520 nonredundant expressed sequence tags (EST) were composed of two nylon membranes ( 8 to $12 \mathrm{~cm}$ each) by a MICROGRID II Robotic workstation (Beckman Instruments, Inc., Fullerton, CA) according to the manufacturer's instruction manual. Macroarray membranes were supplied by the Japanese Solanaceae Genomics Project (JSOL). The list of 11,520 nonredundant EST clones can be found using the MiBASE Micro-Tom database (available online from the Kazusa DNA Research Institute).

Preparation of probes and hybridization. Total RNA was isolated from tomato roots by an RNeasy Plant Mini Kit (Qiagen, Hilden, Germany). Total RNA was reverse transcribed to synthesize $\left[\alpha^{33} \mathrm{P}\right] \mathrm{dCTP}-$ labeled cDNA probes as described previously (23). One set of macroarray membranes was prehybridized with $12 \mathrm{ml}$ of $0.5 \mathrm{M}$ Church phosphate buffer (9) containing $1 \mathrm{mM}$ EDTA, $7 \%$ sodium dodecyl sulfate (SDS), and $12 \mu \mathrm{g}$ of oligo $(\mathrm{dA})_{18}$ in a hybridization bag at $55^{\circ} \mathrm{C}$ for $6 \mathrm{~h}$. Heat-denatured ${ }^{33} \mathrm{P}$-labeled cDNA was mixed with $1 \mathrm{ml}$ of the Church phosphate buffer and then added to the hybridization bag. After incubation at $55^{\circ} \mathrm{C}$ for $20 \mathrm{~h}$, membranes were washed twice with $2 \times \mathrm{SSC}$ ( $1 \times \mathrm{SSC}$ is $0.15 \mathrm{M} \mathrm{NaCl}$ plus $0.015 \mathrm{M}$ sodium citrate) containing $0.1 \%$ SDS at $25^{\circ} \mathrm{C}$ for $5 \mathrm{~min}$, once with $1 \times \mathrm{SSC}$ containing $0.1 \%$ SDS at $65^{\circ} \mathrm{C}$ for $15 \mathrm{~min}$, and twice with $0.1 \times \mathrm{SSC}$ containing $0.1 \% \mathrm{SDS}$ at $65^{\circ} \mathrm{C}$ for $15 \mathrm{~min}$. The membranes were wrapped with plastic film and exposed to an IP (BAS-IP SR 2040) image plate (Fuji Photo Film, Tokyo, Japan) for 3 days.

Data analysis. Signals on the IP image plates were scanned with FXPro (Bio-Rad, Hercules, CA) and quantified using Array Vision 5.1 software (IMAGING Research Inc., Ontario, Canada). Signal intensity was calculated and normalized by a previously described procedure (23). Four replicate experiments were conducted. To select differentially expressed genes between CWPand DW-treated plants, stringent criteria were applied as described next. The average of the normalized value of the signal intensity for each gene in four replicate experiments was adopted as the expression value of the gene. When the value of gene expression was $\leq 0.3$ in one of four treatments, the gene was eliminated for further analysis, because such low intensity data are less reproducible. The average of the normalized value of the signal intensity for each gene in four replicate experiments was adopted as the expression value of the gene. One-way analysis of variance of the expression values was performed to identify the genes having similar altered expression patterns in four replicate experiments. Genes whose expression level was significantly different between CWP and DW treatments were selected using Fisher's least significant difference procedure. The ratio of induction or suppression of each gene was calculated by the expression value for CWP divided by that of DW. Ratios of $<1$ were transformed to $-1 /$ ratio. Then, when the value of gene expression increased more than threefold or decreased to less than fivefold in the CWP-treated plant, we identified the gene expression as altered reproducibly between two treatments. The data were analyzed using Microsoft Excel. 
Northern hybridization analysis. Total RNA was isolated from the roots, stems, and leaves of tomato with an RNeasy PlantMini Kit following the instruction manual. Ten micrograms of total RNA was loaded in each lane of a $1.2 \%$ denaturing agarose gel. Northern hybridization was performed according to a published protocol (42). To detect the expression of basic $P R-2$, LeUBQ5, and eight CWP-inducible genes (i.e., JSOL clone nos. FA29BH06, FA22DA07, FA33AC03, FB17BD03, FA14CF03, FA28DA01, FA25BF10, and FA16CF04 [TIGR LeGI nos. TC116638, TC125475, TC116923, TC116192, TC124613, TC117846, TC126254, and TC116283], respectively), open reading frames of each gene were amplified by reverse polymerase chain reaction (PCR) with the primers 5'-CATGGATGAGAATCTACGTACC-3' and 5'-TATAACAAAACAAACTCAATAC-3' for FA29BH06 (TC116638), 5'-GGAGGGTGAAGCAATGAGGA-3' and 5'-CAAACCTTCTCTCCCATGAC-3' for FA22DA07 (TC125475), 5'-GGAAACCAAAGTTATTTCTA-3' and 5'-TAGTTCTTGAAAAGTTCCAA-3' for FA33AC03 (TC116923), 5'-GGCAAATTTGTTCATTAAGC-3' and 5'-CAATCCAAATTTCCAACTTT-3' for FA28DA01 (TC116192), 5'GGCTGATCTGAAGAAGAAAT-3' and 5'-TACTTCTGCCTCTTATAAAT-3' for FA14CF03 (TC124613), 5'-GGCCAGGAAGAAGATCAGAG-3' and 5'-TATGCAGCTGCACTGATGCA-3' for FB17BD03 (TC117846), 5'-CCATGGGAGCTGGTGGAAATATG-3' and 5'-CTTTCAAAGCTTGTTTTTATACC-3' for FA16CF04 (TC126254), and 5'-CATGGATGAGAATCTACGTACC-3' and 5'-TATAACAAAACAAACTCAATAC-3' for FA25BF10 (TC116283). About 600-bp DNA fragments for detecting tran- scripts from basic $P R-2$ and $L e U B Q 5$ by northern hybridization were also amplified by reverse PCR with primers, i.e., 5'GTGCTTCTAGGATTACTTGTCGCCACC-3' and 5'-CTCACTAGTGAGTGAAGAAGCAGTGC-3' for basic $P R$-2 and 5'-GCAGATCTTCGTGAAAACCC-3' and 5'-CAATCGCCTCCAGCCTTGTT-3' for LeUBQ5. First-strand cDNA as a template for reverse PCR was reverse-transcribed from total RNA of tomato roots with an RT-PCR kit (Invitrogen, Carlsbad, CA). One microgram of first-strand cDNA was added to $50 \mu \mathrm{l}$ of $10 \mathrm{mM}$ Tris- $\mathrm{HCl}(\mathrm{pH} 8.3$ ) containing $50 \mathrm{mM} \mathrm{KCl}, 2 \mathrm{mM} \mathrm{MgCl} 2,0.2 \mathrm{mM}$ each of dATP, dCTP, dGTP, and dTTP, $0.2 \mu \mathrm{M}$ of each primer, and 5 units of Taq DNA polymerase (Promega, Madison, WI) for PCR. The reaction ran with the following program: 30 cycles at $94^{\circ} \mathrm{C}$ for $1 \mathrm{~min}, 55^{\circ} \mathrm{C}$ for $2 \mathrm{~min}$, and $73^{\circ} \mathrm{C}$ for $1 \mathrm{~min}$. The PCR product was puri• ed and cloned into the EcoRV site of pBluescript SK+ (Stratagene, La Jolla, CA). To confirm that the expected DNA had been cloned, the nucleotide sequence of each insert was determined by the Sanger method with the automated DNA sequencer (ABI model 310A; Applied Biosystems, Foster City, CA). The eight amplified CWP-inducible genes, basic $P R-2$, and $L e U B Q 5$ DNA fragments were labeled with $\left[{ }^{32} \mathrm{P}\right] \mathrm{dCTP}$ using the Megaprime DNA labeling systems (Amersham-Pharmacia, Piscataway, NJ).

In order to analyze LeCAS expression in differential tissues of tomato, total RNA was isolated from leaf, stem, and root tissues at $4 \mathrm{~h}$ after treatment of roots with CWP and DW. LeUBQ5 was detected as an internal control. The level of LeCAS expression was quantified by measuring the intensity of each band of northern

TABLE 1. Genes with up- and down-regulated expression in glycoprotein elicitor in the cell wall fraction (CWP)-treated roots of Lycopersicon esculentum cv. Micro-Tom

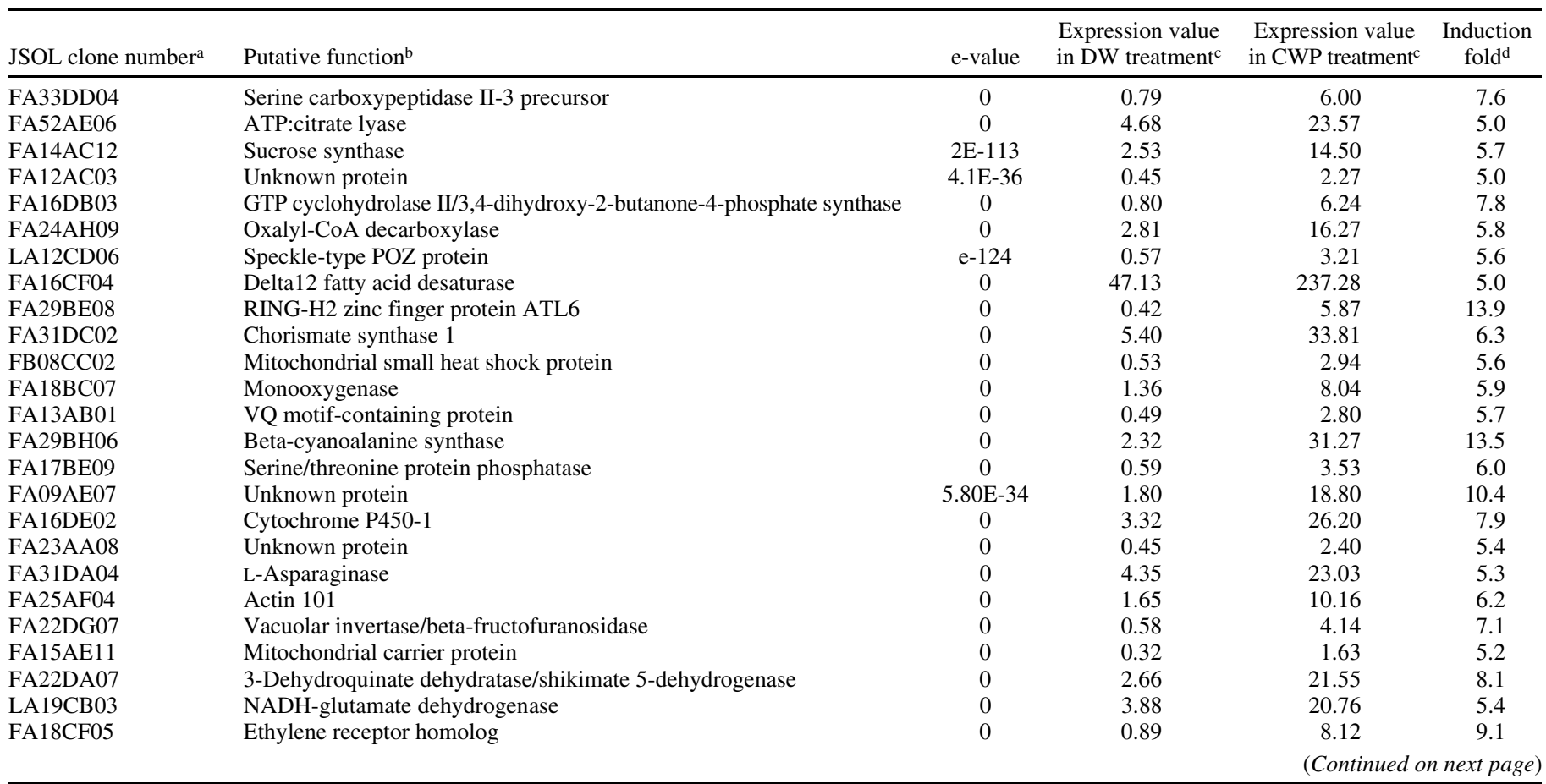

a Japanese Solanaceae Genomics Project (JSOL) numbers were assigned using the MiBASE Micro-Tom database (available online from the Kazusa DNA Research Institute).

${ }^{\mathrm{b}}$ Putative function of each gene product was determined by BLASTN or BLASTX homology search using The Institute for Genomic Research (TIGR) tomato genome index (available online from TIGR website) and GenBank (available online from the National Center for Biotechnology Information/National Institutes of Health website).

${ }^{c}$ The average of the normalized value of the signal intensity for each gene in four replicate experiments was adopted as the expression value of the gene. One-way analysis of variance of the expression values was performed to identify the genes having similar altered expression patterns in four replicate experiments. The gene in which expression level was significantly different between CWP and distilled water (DW) treatments was selected using Fisher's least significant difference procedure $(P<0.05)$.

${ }^{\mathrm{d}}$ Induction or suppression fold of each gene in the roots $4 \mathrm{~h}$ after CWP and DW treatments was calculated by the expression value for CWP divided by that of DW. Ratios of $<1$ were transformed to $-1 /$ ratio. Then, when the value of gene expression increased more than fivefold or decreased less than fivefold in the CWP-treated plant, we identified the gene expression as altered reproducibly between two treatments. Genes with induced or suppressed expression in CWP or DW are divided by dashed line. 
hybridization on IP (BAS-IP SR 2040) image plate using FXPro (Bio-Rad). The means of the expression level and their standard deviation (SD) in three plants were calculated in each experiment.

Plant activator, signal compound, and stress treatments. Fourteen-day-old tomato plants were used for a series of treatments. Three commercial plant activators, i.e., 3-allyloxy-1,2benzisothiazole-1,1-dioxide (Probenazole) (59), benzo(1,2,3) thiadiazole-7-carbothioic acid S-methyl ester (BTH) (44) and [1S$(1 \alpha, 4 \alpha, 5 \beta, 6 \alpha)]-1,5,6$-trideoxy-4- $O$ - $\beta$-D-glucopyranosyl)-5-(hydroxymethyl)-1-[[4,5,6-trihydroxy-3-(hydroxymethyl)-2-cyclohexen-1-yl] amino]-D-chiro-inocitol-1L-(1,3,4/2,6)-2,3-dihydroxy-6-hydroxymethyl-4-[(1S,4R,5S,6S)-4,5,6-trihydroxy-3-hydroxymethylcyclohex-2-enylamino]cyclohexyl-3-D-glucopyranoside) (validamycin A [VMA]) (24), were supplied by Meiji Seika Kaisha, Co. Ltd. (Japan), Syngenta (USA), and Sumitomo Chemical Co. Ltd. (Japan), respectively. Tomato roots were dipped in of one of the three plant activators $(10 \mu \mathrm{g} / \mathrm{ml})$, respectively, and then incubated for $4 \mathrm{~h}$ at $24^{\circ} \mathrm{C}$.

SA, INA, and 1-amino-cyclopropane-1-carboxylate (ACC) were applied by submerging tomato roots in suspensions of formulations in DW for $4 \mathrm{~h}$ at $24^{\circ} \mathrm{C}$. Methyl-jasmonate (MeJA) was similarly applied to roots with the formulation suspension in $0.1 \%$ ethanol for $4 \mathrm{~h}$ at $24^{\circ} \mathrm{C}$. As the controls, tomato roots were treated with DW or $0.1 \%$ ethanol for $4 \mathrm{~h}$ at $24^{\circ} \mathrm{C}$.

Tomato roots were treated with 10 types of environmental abiotic stresses: heat shock at $37^{\circ} \mathrm{C}$ for $4 \mathrm{~h}$; cold shock at $4{ }^{\circ} \mathrm{C}$ for $4 \mathrm{~h}$; mechanical wounding by root sectioning in $\approx 5 \mathrm{~mm}$, and then soaking in DW for $4 \mathrm{~h}$; drought for $1 \mathrm{~h}$; dark for $4 \mathrm{~h}$; and treat- ment with $0.2 \mathrm{M} \mathrm{NaCl}, 0.5 \mathrm{M}$ mannitol, $2 \%$ glucose, and bovine serum albumin (BSA) at $2 \mathrm{mg} / \mathrm{ml}$ for $4 \mathrm{~h}$, respectively.

Measurement of ethylene production. Each plant was treated with ACC in a gas-tight serum flask. At the time of ethylene measurement, 1-ml gas samples were withdrawn through the rubber seal. The concentration of ethylene was determined by gas chromatography (Shimazu, Osaka, Japan) as described previously (20). The means of ethylene concentration and their SD in three plants were calculated in each experiment.

\section{RESULTS}

Up- and down-regulated genes in CWP-treated tomato roots. Macroarray analysis of four independent RNA samples isolated from CWP-treated tomato roots and a DW-treated control indicated that 144 genes were up-regulated more than threefold and 99 genes were down-regulated to less than threefold in response to CWP. A list of these 243 genes and information about the altered level of their gene expression can be found at MiBASE (available online from the Kazusa DNA Research Institute). Table 1 is a list of 65 of the 243 genes that were up-regulated greater than fivefold or down-regulated to less than fivefold by CWP treatment. Defense-related genes (e.g., PR protein P14 and class II chitinase genes), oxidative stress-related genes (e.g., glutathione S-transferase and superoxide dismutase genes), and other stress-related genes are included. Other up-regulated genes in CWP-treated tomato roots were JA- and ethylene-related genes. Expression of genes encoding an ethylene receptor homolog, an

TABLE 1. (Continued from preceding page)

\begin{tabular}{|c|c|c|c|c|c|}
\hline JSOL clone number ${ }^{\mathrm{a}}$ & Putative function $^{\mathrm{b}}$ & e-value & $\begin{array}{l}\text { Expression value } \\
\text { in DW treatment }{ }^{\mathrm{c}}\end{array}$ & $\begin{array}{l}\text { Expression value } \\
\text { in CWP treatment }\end{array}$ & $\begin{array}{l}\text { Induction } \\
\text { fold }^{\mathrm{d}}\end{array}$ \\
\hline FA05AC02 & Amine oxidase & 0 & 0.46 & 2.34 & 5.1 \\
\hline FA25BF10 & Pepper esterase/VCL1 & 0 & 72.68 & 431.01 & 5.9 \\
\hline FB17BH07 & Unknown protein & 0 & 2.64 & 36.43 & 13.8 \\
\hline FA14CF03 & Farnesyl pyrophosphate synthase & 0 & 10.22 & 99.60 & 9.7 \\
\hline FA19DF05 & Acyl-[acyl-carrier protein] desaturase & 0 & 3.31 & 17.87 & 5.4 \\
\hline FA28DA01 & Embryo-abundant protein & 0 & 2.30 & 35.08 & 15.3 \\
\hline FB17AB07 & Lipoxygenase & $5.8 \mathrm{E}-76$ & 0.51 & 2.71 & 5.3 \\
\hline FB18CA01 & Transaldolase & $3.00 \mathrm{E}-09$ & 3.12 & 15.81 & 5.1 \\
\hline LA19CH06 & Jasmonic acid 2 & 0 & 0.32 & 4.22 & 13.0 \\
\hline FA05AG12 & Unknown protein & 0 & 0.67 & 3.61 & 5.3 \\
\hline FA33AC03 & Flavanone 3-hydroxylase-like protein & 0 & 1.36 & 16.21 & 11.9 \\
\hline FB17BD03 & ATP citrate lyase b-subunit & 0 & 1.90 & 20.07 & 10.6 \\
\hline LA11CF04 & ATP:citrate lyase & 0 & 3.56 & 35.21 & 9.9 \\
\hline LC05CA 12 & Unknown protein & $1 \mathrm{E}-21$ & 0.39 & 2.14 & 5.5 \\
\hline $\mathrm{LC} 02 \mathrm{AC} 05$ & AAA-type ATPase family protein & e-135 & 0.39 & 2.10 & 5.3 \\
\hline LC17DA03 & Receptor-like kinase & $9 \mathrm{E}-40$ & 0.31 & 1.82 & 5.8 \\
\hline LA24AH09 & Beta-expansin 2 precursor-like protein & $2 \mathrm{E}-81$ & 1.05 & 11.58 & 11.0 \\
\hline FA06CB 10 & Ovule/fiber cell elongation protein Ghfe 1 & 0 & $8.9 \overline{3}$ & 1.47 & -6.1 \\
\hline FB03CC08 & Unknown protein & 0 & 1.56 & 0.31 & -5.0 \\
\hline FA32CB06 & Peptide transporter & e-160 & 2.29 & 0.36 & -6.3 \\
\hline FA22CC10 & $20 \mathrm{~S}$ proteasome alpha-subunit $\mathrm{C}(\mathrm{PAC} 1)$ & 0.001 & 2.74 & 0.40 & -6.8 \\
\hline FA36CE05 & Unknown protein & 0 & 3.39 & 0.48 & -7.1 \\
\hline FB $10 \mathrm{CC} 08$ & Unknown protein & 0 & 6.42 & 0.87 & -7.4 \\
\hline LA20DH04 & Thiazole biosynthetic enzyme chloroplast precursor & 0 & 6.76 & 0.93 & -7.3 \\
\hline FA36AF06 & T-complex protein 1 epsilon subunit & 0 & 3.33 & 0.54 & -6.2 \\
\hline LA14BH04 & Aquaglyceroporin & 0 & 6.70 & 0.70 & -9.6 \\
\hline FA29AD04 & C-4 sterol methyl oxidase & 0 & 1.88 & 0.35 & -5.4 \\
\hline LA22CE01 & Arginine $N$-methyltransferase-like protein & e-132 & 1.72 & 0.31 & -5.5 \\
\hline LA26CE02 & Apospory-associated protein $\mathrm{C}$ & 0 & 3.06 & 0.31 & -9.9 \\
\hline LB03CE07 & Aquaporin-like protein & 0 & 27.84 & 4.05 & -6.9 \\
\hline LB04DD01 & Serine/threonine-protein kinase orb6 & 0 & 21.35 & 4.07 & -5.2 \\
\hline LC16CC11 & Unknown protein & 0 & 4.82 & 0.94 & -5.1 \\
\hline LC06AG08 & Receptor protein kinase CLAVATA1 & 0 & 2.88 & 0.39 & -7.5 \\
\hline LA25DE02 & Pectinacetylesterase & 0 & 1.96 & 0.35 & -5.6 \\
\hline LB04AF10 & Drought-induced protein SDi-6/early nodulin 12B precursor $(\mathrm{N}-12 \mathrm{~B})$ & 0 & 10.23 & 1.16 & -8.8 \\
\hline LC10DG03 & Auxin response factor 2 & $2 \mathrm{E}-71$ & 2.22 & 0.41 & -5.4 \\
\hline LB01DE07 & Unknown protein & 0 & 2.61 & 0.42 & -6.3 \\
\hline LA24AB07 & Unknown protein & 0 & 2.04 & 0.34 & -6.1 \\
\hline LC15AH02 & Glycerophosphoryl diester phosphodiesterase & 0 & 3.04 & 0.52 & -5.8 \\
\hline LA28DG10 & Unknown protein & $5.4 \mathrm{E}-31$ & 25.10 & 4.11 & -6.1 \\
\hline
\end{tabular}


ethylene responsive transcription factor, alleneoxide synthase and lipoxigenase for JA biosynthesis, and three JA-inducible transcription factors (i.e., JERF1, NAC transcription factor JA2, and MYC transcription factor JA3) was clearly induced in CWPtreated tomato roots. There are many genes encoding enzymes involved in secondary metabolism among the up-regulated genes.

Analysis of CWP-inducible gene expression in tomato roots treated with commercial plant activators. Up-regulation of nine genes expressed in tomato roots at $4 \mathrm{~h}$ after CWP treatment was confirmed by northern hybridization analysis (Fig. 1). Of these nine

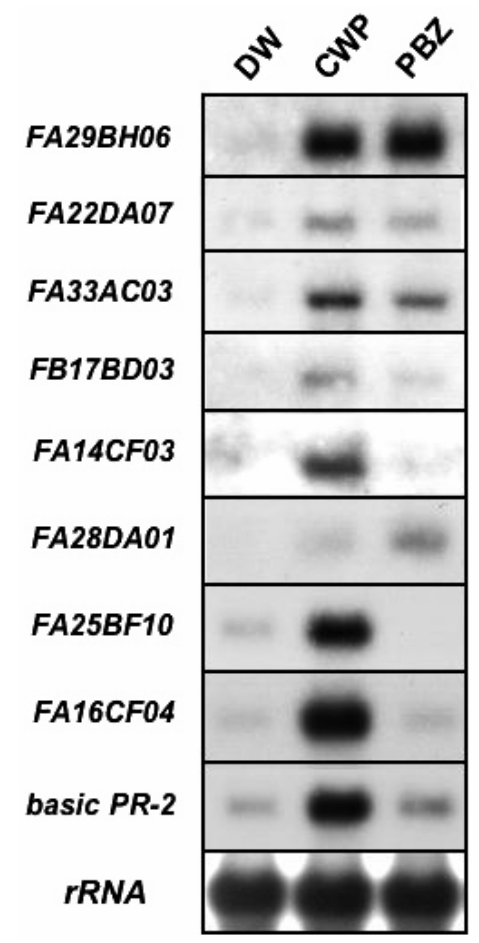

Fig. 1. Northern blot expression analysis of the effect of glycoprotein elicitor in the cell wall fraction (CWP) and 3-allyloxy-1,2-benzisothiazole-1,1-dioxide (PBZ; Probenazole) on transcript abundance of nine genes shown by macroarray analysis to be up-regulated in tomato roots treated with CWP. Tested are J-SOL clone numbers FA29BH06 encoding beta-cyanoalanine synthase, FA22DA07 encoding shikimate 5-dehydrogenase/3-dehydroquinate dehydratase, FA33AC03 encoding flavanone 3-hydroxylase-like protein, FB17BD03 encoding ATP citrate lyase b-subunit, FA14CF03 encoding farnesyl pyrophosphate synthase, FA28DA01 encoding embryo-abundant protein, FA25BF10 encoding pepper esterase, FA16CF04 encoding delta 12 fatty acid desaturase, and basic PR-2. Expression of these nine genes and rRNA are shown $4 \mathrm{~h}$ after treatment with fungal glycoprotein elicitor (CWP), PBZ, and distilled water (DW).

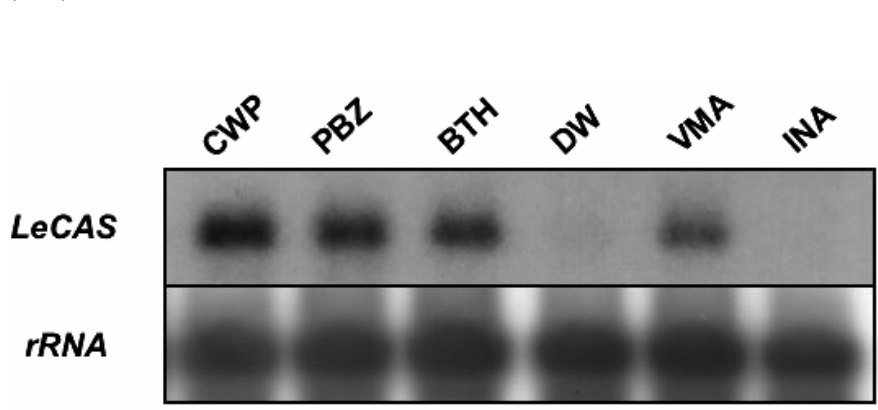

Fig. 2. Northern blot expression analysis of a beta-cyanoalanine synthase gene in tomato roots treated with three commercial plant activators. Expression of the beta-cyanoalanine synthase gene $(L e C A S)$ in tomato roots treated with fungal glycoprotein elicitor (CWP), 3-allyloxy-1,2-benzisothiazole-1,1-dioxide (PBZ), benzo(1,2,3)thiadiazole-7-carbothioic acid S-methyl ester (BTH), validamycin A (VMA), 2,6-dichloroisonicotinic acid (INA), and distilled water (DW) was detected $4 \mathrm{~h}$ after treatment by northern hybridization. rRNA was detected as an internal control. genes, the expression of three genes (i.e., Japanese Solanaceae Genomics Project [JSOL] clone numbers FA29BH06, encoding beta-cyanoalanine synthase [LeCAS]; FA22DA07, encoding shikimate 5-dehydrogenase/3-dehydroquinate dehydratase; and FA33AC03, encoding flavanone 3-hydroxylase-like protein) was also induced at $4 \mathrm{~h}$ in tomato roots after PBZ treatment (Fig. 1).

Because co-induction of these three genes by CWP and PBZ treatments suggests that there may be a conserved molecular process underlying induced resistance by these treatments, the expression of three genes in tomato roots treated with two other commercial plant activators, BTH and VMA, was analyzed. At $4 \mathrm{~h}$ after BTH and VMA treatments, as well as CWP and PBZ treatments, a high level of $L e C A S$ transcript was reproducibly detected (Fig. 2). The expression of two other genes was also significantly up-regulated by treatment with BTH and VMA, but the level of their induction was variable in biological repetition (data not shown). LeCAS was not up-regulated in tomato roots treated with synthetic chemical INA (Fig. 2).

Analysis of LeCAS expression in tomato roots treated with several types of abiotic stress and signaling compounds. LeCAS transcript was abundant in roots, but it accumulated at low level in leaf and stem tissues (Fig. 3A). Although the level of induction of LeCAS in leaf and stem tissues was lower than that in roots, treatment of roots with CWP systemically induced a two- to fourfold increase in the expression of $L e C A S$ even in leaf and stem tissues (Fig. 3A and $\mathrm{B}$ ), indicating that the induction of LeCAS expression is a systemic response to CWP in tomato plants.

The expression of $L e C A S$ was analyzed in tomato roots treated with $\mathrm{BSA}, \mathrm{NaCl}$, mechanical wounding, drought, heat and cold shocks, osmotic stress by mannitol and glucose, and dark treatments. Except for very low induction of LeCAS by cold shock, other abiotic stresses did not induce expression of LeCAS in tomato roots at $4 \mathrm{~h}$ after treatment, whereas expression of LeCAS was significantly induced by CWP (Fig. 4A).
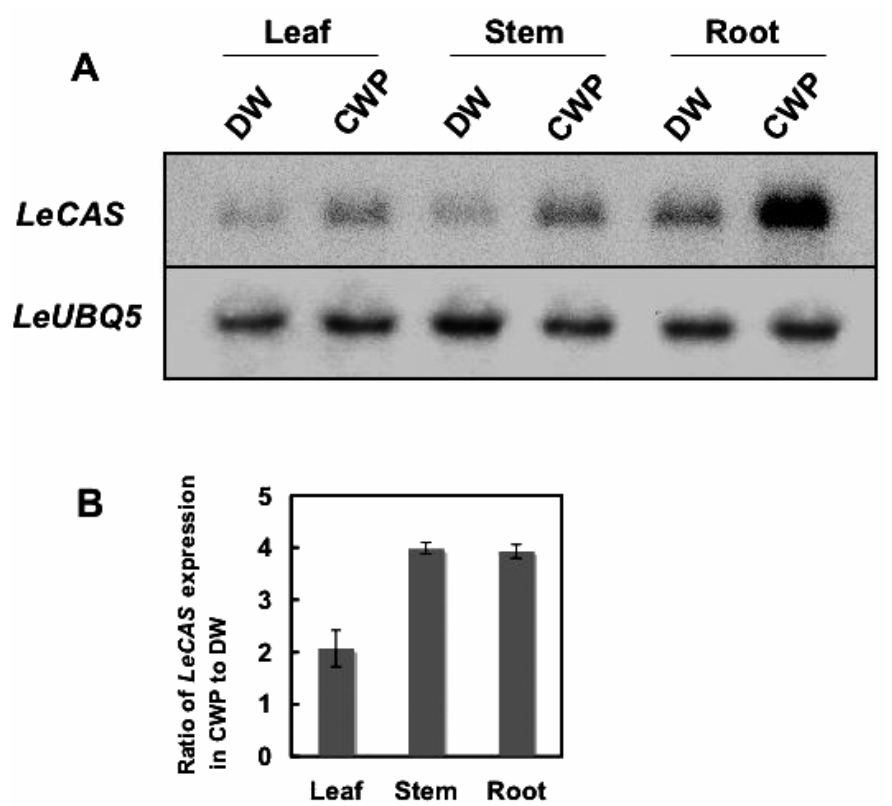

Fig. 3. Northern blot expression analysis of a beta-cyanoalanine synthase gene in tomato tissues after treatment of roots with glycoprotein elicitor in the cell wall fraction (CWP). A, Expression of the beta-cyanoalanine synthase gene $(L e C A S)$ in tomato leaf, stem, and root tissues was detected $4 \mathrm{~h}$ after treatment of roots with fungal glycoprotein elicitor (CWP) and distilled water (DW). Ubiquitin 5 (LeUBQ5) of tomato was detected as an internal control. B, The level of LeCAS expression was quantified by measuring the intensity of each band of northern hybridization on IP image plate using Bio-Rad FX (Bio-Rad, Hercules, CA). The means of the expression level and their standard deviation in three plants were calculated in each experiment. 
SA, JA, and ethylene are thought to be key signaling compounds for induced resistance $(15,43)$. It is known that commercial plant activators accelerate the SA-mediated signal transduction pathway conferring SAR. On the other hand, ISR by $P$. fluorescens is conferred by JA- and ethylene-mediated signaling pathways. To investigate if these signaling pathways are associated with up-regulation of LeCAS in tomato roots by CWP treatment, induction of LeCAS expression by SA, MeJA, and ACC treatments was analyzed. LeCAS expression was induced by ACC, which is a precursor of ethylene, but not by SA and MeJA (Fig. 4B). Transient activation of ethylene production and ethylene-inducible defense gene expression has been identified in tomato roots at $4 \mathrm{~h}$ after CWP treatment (20). The level of LeCAS expression also increased in tomato roots at $4 \mathrm{~h}$ after CWP treatment and then decreased gradually (Fig. 4C). These results indicated that elevated level of LeCAS expression in tomato roots at $4 \mathrm{~h}$ after treatment by CWP and commercial plant activators coincided with ethylene production and may be induced by it.

The amount of ethylene production in ACC-treated tomato roots depends upon the concentration of ACC (Fig. 5B). However, a high level of $L e C A S$ expression was maintained even at a low concentration of ACC, resulting in a low level of ethylene production (Fig. 5A). A high level of LeCAS expression, which was rapidly, sensitively, and specifically induced by CWP and commercial plant activators, seems to be a general phenomenon in the response of tomato roots to fungal elicitors and plant activators.

\section{DISCUSSION}

Pythium oligandrum has been utilized as a biocontrol agent for controlling damping-off of cress caused by Pythium ultimum and has been commercialized as Polygardron (Polyversum) in the Slovak Republic $(5,6)$. The production of CWP of Pythium

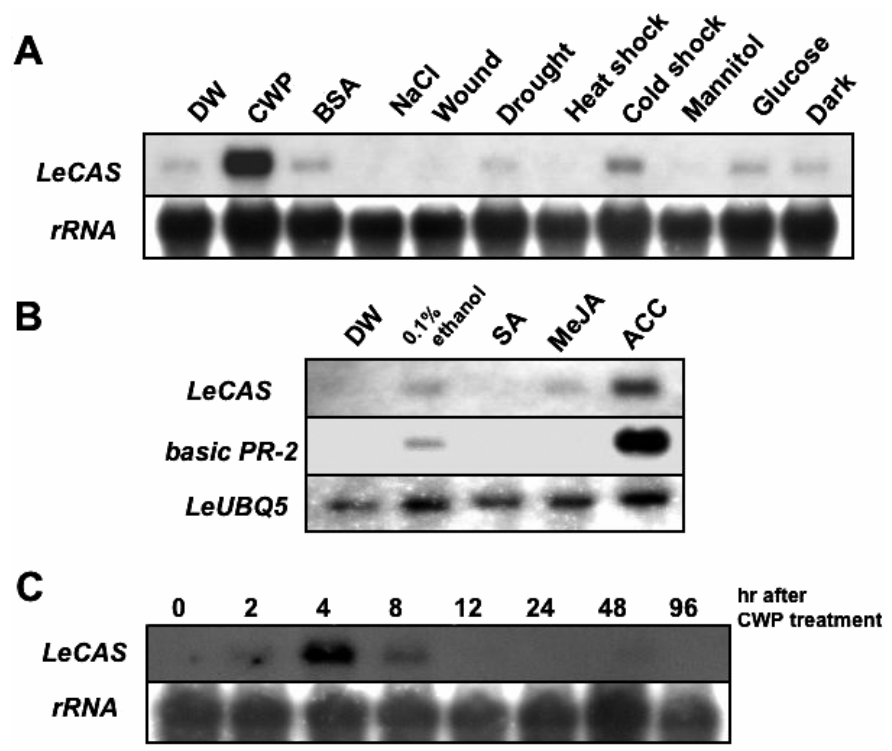

Fig. 4. Northern blot expression analysis of a beta-cyanoalanine synthase gene in response to environmental abiotic stresses and signaling compounds. A, Expression of the beta-cyanoalanine synthase gene (LeCAS) in tomato roots treated with bovine serum albumin (BSA), $\mathrm{NaCl}$, mechanical wounding, drought, heat and cold shocks, and osmotic stress by mannitol and glucose was detected as described in the experimental procedure section. LeCAS expression was also detected in fungal glycoprotein elicitor (CWP)- and distilled water (DW)-treated tomato roots. rRNA was detected as an internal control. B, Induction of LeCAS by salicylic acid (SA), methyl-jasmonate (MeJA), and 1aminocyclopropane-1-carboxylate (ACC), which is a precursor of ethylene, was detected $4 \mathrm{~h}$ after inoculation. Ubiquitin 5 (LeUBQ5) of tomato was detected as an internal control. C, Time course of the elevated level of LeCAS in tomato roots at $0,2,4,8,12,24,48$, and $96 \mathrm{~h}$ after treatment with CWP was analyzed. rRNA was detected as an internal control. oligandrum seems to play an important role in enhancing the potency of Pythium oligandrum to control plant diseases, as shown by the fact that damping-off disease caused by Rhizoctonia solani AG2-2 in sugar beet, Fusarium head blight caused by Fusarium graminearum in wheat, and bacterial wilt disease caused by Ralstonia solanacearum in tomato were suppressed by treatment of their roots with CWP $(20,51)$. In the present experiments, to investigate the molecular mechanism for Pythium oligandruminduced resistance to pathogens, global gene expression in tomato roots treated with CWP was analyzed. Up-regulation of defense and oxidative stress-related genes may result from the activation of conserved defense mechanisms by CWP treatment because they are generally induced in plants in which induced resistance to pathogens has been activated by several plant activators and biocontrol agents $(13,15,17,47,53,57,58)$. Elevated levels of JA and ethylene-related gene expressions were also observed in CWPtreated tomato roots. The activation of the ethylene-mediated signaling pathway has been reported in CWP-treated tomato roots (20). The activation of the JA-mediated signaling pathway is often associated with a defense response to pathogens by combination with co-activation of the ethylene-mediated signaling pathway (15). Therefore, JA- and ethylene-mediated signaling pathways seem be activated by CWP treatment.

Except for up-regulation of genes that are commonly related to the defense response, altered expression of several genes encoding protein kinases, putative transcription factors, and many functional unknown proteins was observed in tomato roots at $4 \mathrm{~h}$ after CWP treatment. Altered expression of these genes may be associated with signal transduction pathways conferring defense induced resistance by CWP treatment. Furthermore, expression of

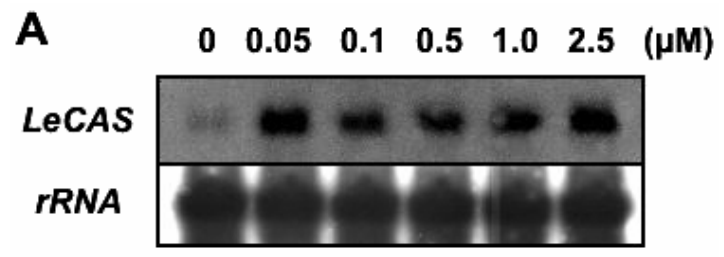

B

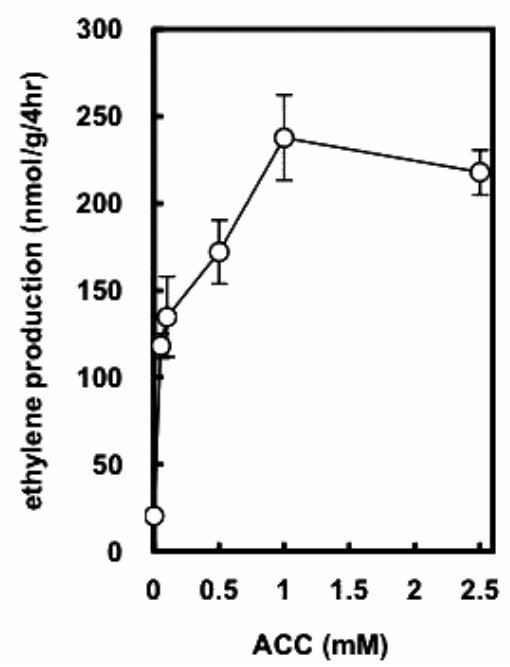

Fig. 5. Northern blot expression analysis of a beta-cyanoalanine synthase gene and ethylene production in response to 1-aminocyclopropane-1-carboxylate (ACC) application. A, Expression of the beta-cyanoalanine synthase gene $(L e C A S)$ in tomato roots treated with different amounts of ACC was detected by northern hybridization. rRNA ( $r R N A)$ was detected as an internal control. $\mathbf{B}$, The amount of ethylene production in tomato roots treated with different amounts of ACC was measured by gas chromatography. Both experiments were conducted using tomato roots at $4 \mathrm{~h}$ after ACC treatment. The means of the amount of ethylene and their standard deviation in roots of three plants were calculated in each experiment. 
genes encoding ATP citrate lyase b-subunit, embryo-abundant protein, and pepper esterase was specifically induced by CWP but not by PBZ (Fig. 2). Therefore, in addition to the activation of the general defense mechanism, certain signaling pathways or metabolic pathways seem to be specifically activated for induced resistance by CWP treatment.

Elucidation of the conserved defense mechanism underlying fungal elicitors and plant activator-induced resistance is likely to be important for understanding the mechanism of induced resistance. In CWP-inducible genes identified by global analysis of gene expression, three genes encoding beta-cyanoalanine synthase (LeCAS), shikimate 5-dehydrogenase/3-dehydroquinate dehydratase, and flavanone 3-hydroxylase-like protein, which were up-regulated more than eightfold by CWP treatment, were identified. Up-regulation of these three genes was also observed in PBZ-treated tomato roots. Co-induction of these three genes by CWP and PBZ treatments suggests that there may be a conserved molecular process underlying induced resistance by these treatments. Among these three genes, the elevated level of LeCAS expression was higher and more stable than that of the other two genes. Furthermore, interestingly, the expression of LeCAS was also similarly induced in BTH- and VMA-treated tomato roots. However, LeCAS expression was not induced by INA. It has been considered that INA can specifically activate the SA-dependent signaling pathway (32). Although the mode of action of PBZ, BTH, and VMA may partially overlap the SA-mediated signaling pathway $(13,17,26,27,63)$, it is quite possible that these plant activators can activate SA-independent signaling pathways. Therefore, an elevated level of LeCAS expression in CWP and plant activator-treated tomato roots may be controlled by SA-independent signaling pathways.

Beta-cyanoalanine synthase (CAS) plays an important role in cyanide metabolism in plants (34). In plants, ethylene is biosynthesized from ACC. ACC is metabolized into ethylene, $\mathrm{HCN}$, $\mathrm{CO}_{2}$, and $\mathrm{H}_{2} \mathrm{O}$, and then $\mathrm{HCN}$ is rapidly detoxified by CAS, thereby recycling the reduced nitrogen of cyanide for amino acid synthesis $(4,18,21,34,62)$. CAS encodes deduced molecular mass of a $38-\mathrm{kDa}$ protein containing the conserved pyridoxal 5'-phosphate binding site. The identity of partial amino acid sequences of CAS with those of the mitochondrial isozyme of cysteine synthase (CS) suggests that CAS is likely to be functional in mitochondria (31). The nucleotide sequence of $C A S$ has been determined in Spinacia oleracea, Arabidopsis thaliana, and Solanum tuberosum and the biochemical property of CAS has been well characterized in them $(21,31)$. Their ortholog in tomato $(\mathrm{LeCAS})$ was assigned among the ESTs of Lycopersicon esculentum. Phylogenetic analysis indicated that CAS and CS are the members of $\alpha$-substituted alanine synthase family (21).

For more than a decade, the induction of ethylene production in cell suspension cultures of tomato and tobacco treated with elicitors from Phytophthora species has been reported by some research groups $(1,40,52)$. The transiently elevated level of ethylene production in CWP-treated tomato roots has also been confirmed (20). Furthermore, flavanone 5-hydroxylase-like protein (JSOL clone no. FA33AC03), which has been identified as ACC oxidase catalyzing ACC to ethylene (19), was up-regulated more than 10fold by CWP (Fig. 2). These findings strongly suggest that expression of $L e C A S$ is induced for detoxifying $\mathrm{HCN}$ resulting from the elevated level of ethylene production in CWP-treated tomato roots.

High level of CAS activity seems to be caused by the general response to ethylene production in plants. However, regulation of $C A S$ gene expression may be diverse. In the case of potato plants, ethylene stimulated CAS activity and the amount of CAS protein, but had no effect on the amount of CAS mRNA (31). This result suggests that $C A S$ expression is regulated posttranscriptionally in potato plants. On the other hand, in birch plants, $C A S$ transcript accumulation increases over 16-fold by exposure to ethylene as well as in CWP-treated tomato plants (54). The mechanism of CAS induction by ethylene production may be different among plant species. Vahala et al. (54) reported that $C A S$ transcript also accumulate in response to ozone $\left(\mathrm{O}_{3}\right)$ which induces ethylene and JA production in birch. Functional ethylene and JA signaling is likely to be required for the induction of CAS by ethylene and $\mathrm{O}_{3}$ in birch. It is apparent that $C A S$ expression is regulated by various signaling pathways.

The level of LeCAS transcript did not increase significantly in tomato roots at $4 \mathrm{~h}$ after mechanical wounding, chilling, or drought, although ethylene production in response to these stresses has been well documented as a general physiological phenomenon in plants (61). As shown in Figure 6, the induction of LeCAS seems to be very sensitive to ethylene production, because $\mathrm{HCN}$ is extremely toxic to plant cells. Therefore, noninduction of LeCAS in tomato roots treated with these types of abiotic stresses may suggest that the level of ethylene production was not elevated at least $4 \mathrm{~h}$ after abiotic stress treatments. On the other hand, LeCAS expression was significantly induced in PBZ-, BTH-, and VMA-treated tomato roots; although, to our knowledge, a significant increase of ethylene production has not been directly observed in PBZ-, BTH-, and VMA-treated plants. The up-regulation of LeCAS in PBZ-, BTH-, and VMA-treated tomato roots seems to indicate that ethylene production may slightly increase in tomato roots at $4 \mathrm{~h}$ after treatment.

Besides induction of LeCAS for the detoxification of $\mathrm{HCN}$, the up-regulation of LeCAS in tomato roots treated with CWP and plant activators can be interpreted in a different way. In the last decade, the molecular mechanisms for induced resistance to pathogens have been extensively studied. However, our understanding about the signaling network for induced resistance is still insufficient. For example, spermine and beta-aminobutyric acid have been reported to be novel signaling compounds for induced resistance $(10,49,60,64)$. Therefore, there is a possibility that uncharacterized ethylene-independent signaling pathways may control upregulation of LeCAS in tomato roots treated with CWP and plant activators.

The discovery of novel plant activators and biocontrol agents that confer induced resistance against a broad range of pathogens is very important for the durable control of plant disease in agricultural production. PBZ, a common plant activator against the rice blast fungus, has long been used in Asia since 1980, but no race overcoming PBZ-induced resistance has been found. However, at present, available effective plant defense activators are limited to specific combinations of crops and pathogens. For screening a candidate with potential as a novel plant activator inducing resistance to other pathogens in other plant species, upregulation of the LeCAS gene is likely to be used as an excellent molecular marker. One simple approach might be to produce tomato plants transformed with an open reading frame of green fluorescent protein under the control $C A S$ promoter. These transgenic plants would provide a system for effective screening of the candidates for novel plant activator compound.

\section{ACKNOWLEDGMENTS}

We thank the Japanese Solanaceae Genomics Project (JSOL) for providing macroarray membranes. This work was supported by a grant of the "Research and Development Program for New Bio-Industry Initiatives" from the Bio-oriented Technology Research Advancement Institute, Japan.

\section{LITERATURE CITED}

1. Basse, C. W., and Boller, T. 1992. Glycopeptide elicitors of stress responses in tomato cells. $N$-linked glycans are essential for activity but act as suppressors of the same activity when released from the glycopeptides. Plant Physiol. 98:1239-1247.

2. Benhamou, N., Rey, P., Chjerif, M., Hockenhull, J., and Tirilly, Y. 1997. Treatment with the mycoparasite, Pythium oligandrum, triggers the 
induction of defense-related reactions in tomato roots upon challenge with Fusarium oxysporum f. sp. radicis-lycopersici. Phytopathology 87:108-122.

3. Benhamou, N., Rey, P., Picard, K., and Tirilly, Y. 1999. Ultrastructural and cytochemical aspects of the interaction between the mycoparasite, Pythium oligandrum, and soilborne pathogens. Phytopathology 89:506517.

4. Blumenthal, S. G., Hendrickson, N. R., Abrol, Y. P., and Conn, E. E. 1968. Cyanide metabolism in higher plants III. The biosynthesis of $\beta$ cyanoalanine. J. Biol. Chem. 243:5302-5307.

5. Brozova, J. 2002. Exploitation of the mycoparasitic fungus Pythium oligandrum in plant protection. Plant Prot. Sci. 38:29-35.

6. Butt, T. M., and Copping, L. G. 2000. Fungal biological control agents. Pestic. Outlook 11:186-191.

7. Cao, H., Bowling, S. A., Gordon, S., and Dong, X. 1994. Characterization of an Arabidopsis mutant that is nonresponsive to inducers of systemic acquired resistance. Plant Cell 6:959-965.

8. Chester, K. S. 1993. The problem of acquired physiological immunity in plants. Quart. Rev. Biol. 8:275-324.

9. Church, G. M., and Gilbert, W. 1984. Genomic sequencing. Proc. Natl. Acad. Sci. USA 81:1991-1995.

10. Cohen, Y., Niderman, T., Mosinger, E., and Fluhr, R. 1994. Beta-aminobutyric acid induces the accumulation of pathogenesis-related proteins in tomato (Lycopersicon esculentum L.) plants and resistance to late blight infection caused by Phytophthora infestans. Plant Physiol. 104:59-66.

11. Delaney, T. P., Friedrich, L., and Ryals, J. A. 1995. Arabidopsis signal transduction mutant defective in chemically and biologically induced disease resistance. Proc. Natl. Acad. Sci. USA 92:6602-6606.

12. Durrant, W. E., and Dong, X. 2004. Systemic acquired resistance. Annu. Rev. Phytopathol. 42:185-209.

13. Friedrich, L., Lawton, K., Ruess, W., Masner, P., Specker, N., Rella, M. G., Meier, B., Dincher, S., Staub, T., Uknes, S., Metraux, J.-P., Kessmann, H., and Ryals, J. 1996. A benzothiadiazole derivative induces systemic acquired resistance in tobacco. Plant J. 10:61-70.

14. Gaffney, T., Friedrich, L., Vernooij, B., Negrotto, D., Nye, G., Ukes, S., Ward, E., Kessmann, H., and Ryals, J. 1993. Requirement for salicylic acid for the induction of systemic acquired resistance. Science 261:754756.

15. Glazebrook, J. 2001. Genes controlling expression of defense responses in Arabidopsis-2001 status. Curr. Opin. Plant Biol. 4:301-308.

16. Glazebrook, J., Rogers, E. E., and Ausubel, F. M. 1996. Isolation of Arabidopsis mutants with enhanced disease susceptibility by direct screening. Genetics 143:973-982.

17. Gorlach, J., Volrath, S., Knauf-Beiter, G., Hengy, G., Beckhove, U., Kogel, K.-H., Oostendorp, M., Staub, T., Ward, E., Kessmann, H., and Ryals, J. 1996. Benzothiadiazole, a novel class of inducers of systemic acquired resistance, activates gene expression and disease resistance in wheat. Plant Cell 8:629-643.

18. Gouldey, J. S., Tittle, F. L., and Spencer, M. S. 1989. A role for ethylene in the metabolism of cyanide by higher plants. Plant Physiol. 89:13061310 .

19. Hamilton, A. J., Bouzayen, M., and Grierson, D. 1991. Identification of tomato gene for ethylene-forming enzyme by expression in yeast. Proc. Natl. Acad. Sci. USA 88:7434-7437.

20. Hase, S., Shimizu, A., Nakaho, K., Takenaka, S., and Takahashi, H. 2006. Pythium oligandrum induces transient ethylene production and reduces the severity of bacterial wilt disease caused by Ralstonia solanacearum in tomato. Plant Pathol. (In press.)

21. Hatzfeid, Y., Maruyama, A., Schmidt, A., Noji, M., Ishizawa, K., and Saito, K. 2000. $\beta$-Cyanoalanine synthase is a mitochondrial cysteine synthase-like protein in spinach and Arabidopsis. Plant Physiol. 123: 1163-1171.

22. Huet, J. C., Le Care, J. P., Nespulous, C., and Pernollet, J. C. 1995. The relationships between the toxicity and the primary and secondary structures of elicitin like protein elicitors secreted by the phytopathogenic fungus Pythium vexans. Mol. Plant-Microbe Interact. 8:302-310.

23. Ishihara, T., Sakurai, N., Sekine, K.-T., Hase, S., Ikegami, M., Shibata, D., and Takahashi, H. 2004. Comparative analysis of expressed sequence tags in resistant and susceptible ecotypes of Arabidopsis thaliana infected with Cucumber mosaic virus. Plant Cell Physiol. 45:470-480.

24. Ishikawa, R., Shirouzu, K., Nakashita, H., Lee, H.-Y., Motoyama, T., Yamaguchi, I., Teraoka, T., and Arie, T. 2005. Foliar spray of validamycin A or validoxylamine A controls tomato Fusarium wilt. Phytopathology 95:1209-1216.

25. Kamoun, S., Lindqvist, H., and Govers, F. 1997. A novel class of elicitinlike genes from Phytophthora infestans. Mol. Plant-Microbe Interact. 10:1028-1030.

26. Kessmann, H., Staub, T., Hofmann, C., Maetzke, T., Herzog, J., Ward, E., Uknes, S., and Ryals, J. 1994. Induction of systemic acquired resistance in plants by chemicals. Annu. Rev. Phytopathol. 32:439-459.
27. Lawton, K. A., Friedrich, L., Hunt, M., Weymann, K., Delaney, T., Kessmann, H., Staub, T., and Ryals, J. 1996. Benzothiadiazole induces disease resistance in Arabidopsis by activation of the systemic acquired resistance signal transduction pathway. Plant J. 10:71-82.

28. Lewis, K., Whipps, J. M., and Cooke, R. C. 1989. Mechanisms of biological disease control with special reference to the case study of Pythium oligandrum as an antagonist. Pages 191-217 in: Biotechnology of Fungi for Improving Plant Growth. J. M. Whipps and R. D. Lumdsen, eds. Cambridge University Press, Cambridge.

29. Maleck, K., Levine, A., Eulgem, T., Morgan, A., Schmid, J., Lawton, K. A., Dangl, J. L., and Dietrich, R. A. 2000. The transcriptome of Arabidopsis thaliana during systemic acquired resistance. Nat. Genet. 26:403410.

30. Martin, F. N., and Hancock, J. G. 1987. The use of Pythium oligandrum for biological control of preemergence damping-off caused by $P$. ultimum. Phytopathology 77:1013-1020.

31. Maruyama, A., Saito, K., and Ishizawa, K. 2001. $\beta$-Cyanoalanine synthase and cysteine synthase from potato: Molecular cloning, biochemical characterization, and spatial and hormonal regulation. Plant Mol. Biol. 46:749-760.

32. Metraux, J. P., Ahl Goy, P., Staub, T., Speich, J., Steinemann, A., Ryals, J., and Ward, E. 1991. Induced systemic resistance in cucumber in response to 2,6-dichloro-isonicotinic acid and pathogens. Pages 432-439 in: Advances in Molecular Genetics of Plant-Microbe Interactions. H. Hennecke and D. P. S. Verma, eds. Kluwer Academic Publishers, Dordrecht, The Netherlands.

33. Panabieres, F., Ponchet, M., Allasia, V., Cardin, L., and Ricci, P. 1997. Characterization of border species among Pythiaceae: Several Pythium isolates produce elicitins, typical proteins from Phytophthora spp. Mycol. Res. 101:1459-1468.

34. Peiser, G. D., Wang, T.-T., Hoffman, N. E., Yang, S. F., Liu, H.-W., and Walsh, C. T. 1984. Formation of cyanide from carbon 1 of 1-aminocyclopropane-1-carboxylic acid during its conversion to ethylene. Proc. Natl. Acad. Sci. USA 81:3059-3063.

35. Picard, K., Ponchet, M., Blein, J. P., Rey, P., Tirilly, Y., and Benhamou, N. 2000. Oligandrin. A proteinaceous molecule produced by the mycoparasite Pythium oligandrum induces resistance to Phytophthora parasitica infection in tomato plants. Plant Physiol. 124:379-395.

36. Pieterse, C. M. J., Van Wees, S. C. M., Hoffland, E., Van Pelt, J. A., and Van Loon, L. C. 1996. Systemic resistance in Arabidopsis induced by biocontrol bacteria is independent of salicylic acid and pathogenesisrelated gene expression. Plant Cell 8:1225-1237.

37. Pieterse, C. M. J., Van Wees, S. C. M., Ton, J., Van Pelt, J. A., and Van Loon, L. C. 2002. Signaling in rhizobacteria-induced systemic resistance in Arabidopsis thaliana. Plant Biol. 4:535-544.

38. Pieterse, C. M. J., Van Wees, S. C. M., Van Pelt, J. A., Knoester, M., Laan, R., Gerrits, H., Weisbeek, P. J., and Van Loon, L. C. 1998. A novel signaling pathway controlling induced systemic resistance in Arabidopsis. Plant Cell 10:1571-1580.

39. Ponchet, M., Panabieres, F., Milat, M.-L., Mikes, V., Montillet, J.-L., Suty, L., Triantaphylides, C., Tirilly, Y., and Blein, J.-P. 1999. Are elicitins cryptograms in plant-oomycete communications? Cell. Mol. Life Sci. 56:1020-1047.

40. Rickauer, M., Fournier, J., and Esquerre-Tugaye, M.-T. 1989. Induction of proteinase inhibitors in tobacco cell suspension culture by elicitors of Phytophthora parasitica var. nicotianae. Plant Physiol. 90:1065-1070.

41. Ryu, C.-M., Hu, C.-H., Reddy, M. S., and Kloepper, J. W. 2003. Different signaling pathways of induced resistance by rhizobacteria in Arabidopsis thaliana against two pathovars of Pseudomonas syringae. New Phytol. 160:413-420.

42. Sambrook, J., and Russell, D. W. 2001. Molecular Cloning: A Laboratory Manual. 3rd ed. Cold Spring Harbor Laboratory, Cold Spring Harbor, NY.

43. Schenk, P. M., Kazan, K., Wilson, I., Anderson, J. P., Richmond, T., Somerville, S. C., and Manners, J. M. 2000. Coordinated plant defense responses in Arabidopsis revealed by microarray analysis. Proc. Natl. Acad. Sci. USA 97:11655-11660.

44. Schurter, R., Kunz, W., and Nyteler, R. 1987. Process and a composition for immunizing plants against diseases. U.S. Patent No. 4,931,581. Issued 5 June 1990.

45. Shah, J., Tsui, F., and Klessig, D. F. 1997. Characterization of a salicylic acid-insensitive mutant (sail) of Arabidopsis thaliana identified in a selective screen utilizing the SA-inducible expression of the tms 2 gene. Mol. Plant-Microbe Interact. 10:69-78.

46. Shibata, D. 2005. Genome sequencing and functional genomics approaches in tomato. J. Gen. Plant Pathol. 71:1-7.

47. Shimono, M., Yazaki, J., Nakamura, K., Kishimoto, N., Kikuchi, S., Iwano, M., Yamamoto, K., Sakata, K., Sasaki, T., and Nishiguchi, M. 2003. cDNA microarray analysis of gene expression in rice plants treated with probenazole, a chemical inducer of disease resistance. J. Gen. Plant Pathol. 69:76-82. 
48. Takahashi, H., Shimizu, A., Arie, T., Rosmalawati, S., Fukushima, S., Kikuchi, M., Hikichi, Y., Kanda, A., Takahashi, A., Kiba, A., Ohnishi, K., Ichinose, Y., Taguchi, F., Yasuda, C., Kodama, M., Egusa, M., Masuta, C., Sawada, H., Shibata, D., Hori, K., and Watanabe, Y. 2005. Catalog of Micro-Tom tomato responses to common fungal, bacterial and viral pathogens. J. Gen. Plant Pathol. 71:8-22.

49. Takahashi, Y., Uehara, Y., Berberich, T., Ito, A., Saitoh, H., Miyazaki, A., Terauchi, R., and Kusano, T. 2004. A subset of hypersensitive response marker genes, including HSR203J, is the downstream target of a spermine signal transduction pathway in tobacco. Plant J. 40:586-595.

50. Takenaka, S., and Kawasaki, S. 1994. Characterization of alanine-rich, hydroxyproline-containing cell wall proteins and their application for identifying Pythium species. Physiol. Mol. Plant Pathol. 45:249-261.

51. Takenaka, S., Nishio, Z., and Nakamura, Y. 2003. Induction of defense reactions in sugar beet and wheat by treatment with cell wall protein fractions from the mycoparasite Pythium oligandrum. Phytopathology 93:1228-1232.

52. Toppan, A., and Esquerre-Tugate, M.-T. 1984. Cell surfaces in plantmicroorganism interactions. IV. Fungal glycopeptides which elicit the synthesis of ethylene in plants. Plant Physiol. 75:1133-1138.

53. Uknes, S., Mauch-Mani, B., Moyer, M., Potter, S., Williams, S., Dincher, S., Chandler, D., Slusarenko, A., Ward, E., and Ryals, J. 1992. Acquired resistance in Arabidopsis. Plant Cell 4:645-656.

54. Vahala, J., Ruonala, R., Keinanen, Tuominen, H., and Kangasjarvi, J. 2003. Ethylene insensitivity modulates ozone-induced cell death in birch. Plant Physiol. 132:185-195.

55. Van Loon, L. C., Bakker, P. A. H. M., and Pieterse, C. M. J. 1998. Systemic resistance induced by rhizosphere bacteria. Annu. Rev. Phytopathol. 36:453-483.
56. Van Wees, S. C., Pieterse, C. M., Trijssenaar, A., Van Westende, Y. A. Hartog, F., and Van Loon, L. C. 1997. Differential induction of systemic resistance in Arabidopsis by biocontrol bacteria. Mol. Plant-Microbe Interact. 10:716-724.

57. Verhagen, B. W. M., Glazebrook, J., Zhu, T., Chang, H.-S., Loon, L. C. V., and Pieterse, C. M. J. 2004. The transcriptome of rhizobacteria-induced systemic resistance in Arabidopsis. Mol. Plant-Microbe Interact.17:895908.

58. Wang, Y., Ohara, Y., Nakayashiki, H., Tosa, Y., and Mayama, S. 2005. Microarray analysis of the gene expression profile induced by the endophytic plant growth-promoting rhizobacteria, Pseudomonas fluorescens FPT9601-T5 in Arabidopsis. Mol. Plant-Microbe Interact. 18:385-396.

59. Watanabe, T., Igarashi, H., Matsumoto, K., Seki, S., Mase, S., and Sekizawa, Y. 1977. The characteristics of probenazole (Oryzemate) of the control of rice blast. J. Pestic. Sci. 2:291-296.

60. Yamakawa, H., Kamada, H., Satoh, M., and Ohashi, Y. 1998. Spermine is a salicylate-independent endogenous inducer for both tobacco acidic pathogenesis-related proteins and resistance against tobacco mosaic virus infection. Plant Physiol. 118:1213-1222.

61. Yang, S. F., and Hoffman, N. E. 1984. Ethylene biosynthesis and its regulation in higher plants. Annu. Rev. Plant Physiol. 35:155-189.

62. Yip, W.-K., and Yang, S. F. 1988. Cyanide metabolism in relation to ethylene production in plant tissues. Plant Physiol. 88:473-476.

63. Yoshioka, K., Nakashita, H., Klessig, D. F., and Yamaguchi, I. 2001. Probenazole induces systemic acquired resistance in Arabidopsis with a novel type of action. Plant J. 25:149-157.

64. Zimmerli, L., Jakab, G., Métraux, J.-P., and Mauch-Mani, B. 2000 Potentiation of pathogen-specific defense mechanisms in Arabidopsis by $\beta$-aminobutyric acid. Proc. Natl. Acad. Sci. USA 97:12920-12925. 